\title{
SUPERVISI AKADEMIK KEPALA SEKOLAH DAN MOTIVASI BERPRESTASI DILIHAT DARI PRODUKTIVITAS KERJA GURU SEKOLAH MENENGAH PERTAMA
}

\author{
Dadang Suhendar ${ }^{1}$ \\ ${ }^{1}$ Universitas Wiralodra, Jln. Ir. H. Juanda Km 3 Indramayu, \\ dadangsuhendar_pasca@unwir.ac.id
}

\begin{abstract}
ABSTRAK
Perhatian utama pembahasan dalam penelitian ini adalah menyangkut supervisi akademik kepala sekolah dan motivasi berprestasi serta pengaruhnya terhadap produktivitas kerja guru SMP Negeri di Kecamatan Balongan Kabupaten Indramayu baik secara parsial maupun ganda. Metode penelitian menggunakan metoda survey terhadap guru SMP Negeri di Kecamatan Balongan Kabupaten Indramayu. Teknik pengumpulan data, selain melaksanakan observasi langsung, mengadakan wawancara dengan pihak terkait, dan menyebarkan angket terhadap 59 orang responden. Hasil penelitian menyatakan bahwa: (1) Terdapat pengaruh yang positif dan signifikan supervisi akademik kepala sekolah terhadap produktivitas kerja guru SMP Negeri di Kecamatan Balongan Kabupaten Indramayu. Adapun besaran pengaruhnya setelah melalui perhitungan regresi parsial adalah sebesar $16,2 \%$, sementara selebihnya sebanyak 83,8 \% merupakan pengaruh lain. (2) Terdapat pengaruh yang positif dan signifikan motivasi berprestasi terhadap produktivitas kerja guru SMP Negeri di Kecamatan Balongan Kabupaten Indramayu. Adapun besaran pengaruhnya setelah melalui perhitungan regresi parsial adalah sebesar 31,6\%, sementara selebihnya sebanyak 68,4 \% merupakan pengaruh lain. (3) Terdapat pengaruh yang positif dan signifikan supervisi akademik kepala sekolah dan motivasi berprestasi secara simultan terhadap produktivitas kerja guru SMP Negeri di Kecamatan Balongan Kabupaten Indramayu. Adapun besaran pengaruhnya setelah melalui perhitungan regresi ganda adalah sebesar 36,9\%, sementara selebihnya sebanyak 63,1\% merupakan pengaruh lain.
\end{abstract}

Kata kunci: Supervisi Akademik, Motivasi Berprestasi, Produktivitas Kerja

\section{PENDAHULUAN}

Pentingnya posisi guru diakui dalam Peraturan Pemerintah No.38 tahun 1992 yang diperbaharui dengan Peraturan Pemerintah nomor 39 tahun 2000, yang menyatakan bahwa tenaga pendidik merupakan unsur terpenting dalam sistem pendidikan nasional yang diadakan dan dikembangkan untuk menyelenggarakan pengajaran, pembimbingan dan pelatihan bagi peserta didik. Karena merupakan unsur penting itu pula DPR RI dan Presiden telah mengesahkan Undang Undang tentang Guru dan Dosen pada tahun 2005, dimana didalam pasal 2 termaktub bahwa guru mempunyai kedudukan sebagai tenaga profesional pada jenjang pendidikan dasar, pendidikan menengah, dan pendidikan anak usia dini pada jalur pendidikan formal yang diangkat sesuai dengan peraturan perundangundangan. 
Lebih jelas disebutkan dalam Peraturan Pemerintah No.19 Tahun 2005 tentang Standar Nasional Pendidikan bahwa pendidik (dalam hal ini guru) harus memiliki kualifikasi akademik dan kompetensi sebagai agen pembelajaran, sehat jasmani dan rohani, serta memiliki kemampuan untuk mewujudkan tujuan pendidikan nasional. Kualifikasi akademik untuk guru dari mulai guru pada pendidikan anak usia dini hingga sekolah menengah atas atau sederajat adalah sekurang-kurangnya diploma empat (D-IV) atau sarjana (S1) berlatar belakang pendidikan tinggi dengan program pendidikan yang sesuai dengan mata pelajaran yang diajarkan. Rendahnya kualitas dan kompetensi guru juga menjadi penyebab merosotnya citra profesi.Kondisi objektif di lapangan menunjukkan sebagian guru kurang memahami dan menguasai kurikulum, pelaksanaan evaluasi hasil belajar, pengembanganbahan ajar, serta keterampilan dalam menggunakan metode dan media pembelajaran.

Fatah (2005) mengungkapkan berkenaan dengan tingkat kesesuaian guru mengajar, 15\% guru mengajar tidak sesuai dengan keahlian yang digelutinya. Padahal, menurutnya, guru yang mengajar sesuai bidang studinya pun masih banyak yang tidak menguasai materi ajar yang disampaikan. Contohnya, sebuah tes matematika yang diujikan kepada guru matematika menunjukkan, dari 10 soal yang diberikan, ada guru yang hanya mampu menjawab dengan benar sebanyak 2 soal.

Ketika mengadakan overview observation pada sekolah yang dijadikan tempat penelitian dijumpai beberapa hal yang kurang sewajarnya jika dikaitkan dengan produktivitas kerja guru, di antaranya: (1) Guru hanya melaksanakan pekerjaan sesuai dengan tugas yang dibebankan kepadanya, terpaku dengan rutinitas sehingga pekerjaan hanya dilaksanakan seperlunya saja; (2) Para pendidik terlihat kurang memiliki motivasi kerja yang memadai, semangat kerja masih jauh dari harapan; (3) Guru kurang memiliki orientasi pekerjaan yang positif; (4) Guru belum memperlihatkan kedewasaan dalam berkarya. Padahal kedewasaan merupakan suatu atribut pribadi yang dinilai penting oleh peserta didik; (5) Interaksi sosial dalam pergaulan di sekolah terlihat kurang efektif, sehingga cenderung kurang solid.Di dalam melaksanakan tugasnya, guru harus menguasai ilmu yang diajarkan, menguasai berbagai metode pengajaran, dan mengenal serta memahami anak didiknya.

Pada pengelolaan sekolah yang berperan dan paling bertanggung jawab menghadapi perubahan adalah Kepala Sekolah. Kepala Sekolah adalah pemimpin satuan pendidikan yang bertugas melaksanakan administrasi, pengelolaan, pengembangan, pengawasan, dan 
pelayanan teknis untuk menunjang proses pendidikan pada satuan pendidikan yang dipimpinnya. Sebagai pemimpin pendidikan di sekolah, kepala sekolah memiliki tanggung jawab legal untuk mengembangkan staf, kurikulum, dan pelaksanaan pendidikan disekolahnya (Depdiknas, 2007). Kepala sekolah memegang peranan penting dalam menggerakkan kehidupan sekolah untuk mencapai tujuan. Wahjosumidjo (2003:89) menyatakan bahwa "sebagai kekuatan sentral yang menjadi penggerak kekuatan sekolah, kepala sekolah harus memahami tugas dan fungsinya guna mencapai keberhasilan sekolah serta memiliki kepedulian terhadap staf dan siswa". Salah satu fungsi Kepala Sekolah adalah melaksanakan pengawasan termasuk supervisi akademik. Pelaksanaan supervisi akademik merupakan faktor pendorong terwujudnya motivasi kerja yang pada gilirannya dapat meningkatkan produktivitas kerja.

Penelitian ini bertujuan untuk:

1) Penelitian Mengetahui dan menganalisis besaran pengaruh supervisi akademik kepala sekolah terhadap produktivitas kerja guru SMP Negeri di Kecamatan Balongan Kabupaten Indramayu.

2) Mengetahui dan menganalisis besaran pengaruh motivasi berprestasi terhadap produktivitas kerja guru SMP Negeri di Kecamatan Balongan Kabupaten Indramayu.

3) Mengetahui dan menganalisis besaran pengaruh supervisi akademik kepala sekolah dan motivasi berprestasi secara simultan terhadap produktivitas kerja guru SMP Negeri di Kecamatan Balongan Kabupaten Indramayu.

\section{METODE PENELITIAN}

Pendekatan yang digunakan dalam penelitian ini adalah pendekatan kuantitatif dengan metode deskriptif asosiatif yang diasumsikan bahwa dunia merupakan realitas tunggal yang diukur dengan instrumen, bertujuan untuk mencari hubungan dan menjelaskan sebab perubahan fakta sosial (Schumacher, S dan Mc. Millan.J, 2001:15). Penelitian ini dilakukan di SMP Negeri di Kecamatan Balongan dengan populasi adalah seluruh guru SMP Negeri di Kecamatan Balongan Kabupaten Indramayu yang masih aktif mengajar sampai penelitian dilakukan, yang berjumlah 59 orang. Dalam penelitian ini yang menjadi populasi adalah seluruh guru pada SMP Negeri di Kecamatan Balongan Kabupaten Indramayu yang masih aktif mengajar sampai penelitian dilakukan, yang berjumlah 59 orang. Dalam penelitian ini indikator/dimensi dari variabel supervisi akademik kepala sekolah dengan dimensi: (1) Perencanaan; (2) Pelaksanaan; (3) Tindak 
lanjut (Glickman, 1981). Variabel motivasi berprestasi dengan dimensi: (1) Senang memikul tanggung jawab; (2) Menghindari pekerjaan berisiko; (3) Senang dengan informasi umpan balik; (4) Butuh pengkuan atas prestasi; (5) Senang bekerja sendiri (Bernard, 2001). Variabel tersebut adalah produktivitas kerja guru dengan dimensi: (1) Lebih dari sekedar memenuhi kualifikasi pekerjaan; (2) Bermotivasi tinggi; (3) Mempunyai orientasi pekerjaan yang positif; (4) Dewasa; (5) Dapat bergaul dengan efektif (Ranftl dalam Timpe, 2000).

Teknik pengumpulan data yang digunakan dalam penelitian ini yakni studi literature/ dokumentasi dan kuesioner/ angket. Skala yang digunakan adalah skala Likert untuk ketiga variabel berskala pengukuran ordinal. Analisis data pada penelitian ini yaitu, diuji validitasnya kepada responden dengan menggunakan korelasi Product Moment sebelum kuesioner digunakan. Jika semua item sudah valid maka dilanjutkan dengan pengujian reliabilitas menggunakan rumus "alpha" dari Spearman Brown. Data yang diperoleh perlu melalui uji persyaratan pengolahan data, dalam penelitian ini meliputi uji normalitas yaitu uji liliefors, dan uji linearitas regresi.

\section{HASIL DAN PEMBAHASAN}

Berdasarkan hasil pengolahan data dari angket yang telah disebar kepada responden yang terdiri dari 59 orang Guru SMP Negeri di Kecamatan Balongan, didapat beberapa klasifikasi karakteristik reponden yaitu berdasarkan jenis kelamin, usia, tingkat pendidikan dan masa kerja, sebagai berikut.

Responden yang dikelompokkan berdasarkan jenis kelamin, diketahui jumlah responden laki-laki adalah 27 orang atau $45,76 \%$ dan responden perempuan adalah 32 orang atau 54,24\%. Responden berdasarkan variasi usia, untuk yang rentang usia 20 hingga 30 tahun berjumlah 4 responden, atau sebanyak 6,78\%, Untuk rentang usia 31 sampai dengan 40 tahun berjumlah 29 responden atau sebanyak 49,15\%. Responden dengan rentang usia antara 41 hingga 50 tahun sebanyak 15 orang atau 25,42\%. Selanjutnya, responden dengan rentang usia antara 51 hingga 60 tahun adalah sebanyak 11 atau 18,64 $\%$.

Responden berdasarkan tingkat pendidikan diketahui Diploma IV sebanyak 3 orang atau 5,08\%. Responden dengan pendidikan tertinggi Strata 1 merupakan responden terbanyak yaitu 54 orang atau 91,53\%. Sedangkan responden yang berpendidikan tertinggi Strata 2 sebanyak 2 orang atau 3,39\%. Dengan demikian tingkat pendidikan guru SMP 
Negeri di Kecamatan Balongan telah memenuhi syarat sesuai Undang-undang Tahun 2005 bahwa Guru dan Dosen yang mempersyaratkan guru berpendidikan minimal Diploma IV atau Strata 1. Malah terdapat nilai lebih yaitu sudah ada yang berpendidikan Strata 2.

Sedangkan responden berdasarkan masa kerja didapat bahwa mayoritas responden telah bekerja antara 11 hingga 20 tahun yaitu sebanyak 27 orang atau 45,76\%, disusul dengan yang sudah bekerja sebagai guru antara 21 hingga 30 tahun sebanyak 15 orang atau $25,42 \%$. Guru yang sudah bekerja antara 31 hingga 40 tahun sebanyak 10 orang atau $16,95 \%$, dan sisanya sebanyak 7 orang atau $11,86 \%$ baru bekerja kurang dari 10 tahun.

Selanjutnya dilakukan analisis data dan seleksi data. Dari hasil penyeleksian diperoleh angket yang disebarkan sebanyak 59 angket terkumpul kembali 59. Maka untuk selanjutnya angka 59 yang dijadikan dasar perhitungan sesuai jumlah angket yang terkumpul. Kemudian dilakukan tabulasi dengan hasil sebagai berikut, kriteria interpretasi skor variabel supervisi akademik kepala sekolah setingkat 59,19\% tergolong sedang, kriteria interpretasi skor variabel motivasi berprestasi setingkat $60,18 \%$ tergolong tinggi, kriteria interpretasi skor variabel produktivitas kerja guru setingkat $63,83 \%$ tergolong tinggi.

Hasil uji normalitas diperoleh bahwa data variabel $\mathrm{X}_{1}$ (supervisi akademik kepala sekolah) didapat nilai probabilitas di atas $0,05(0,200>0,05)$ maka distribusi variabel $\mathrm{X}_{1}$ adalah normal. Sementara uji normalitas data variabel $\mathrm{X}_{2}$ (motivasi berprestasi) didapat nilai probabilitas di atas $0,05(0,200>0,05)$ maka distribusi variabel $\mathrm{X}_{2}$ (motivasi berprestasi) adalah normal. Selanjutnya uji normalitas data variabel Y (produktivitas kerja guru) didapat nilai probabilitas di atas $0,05(0,200>0,05)$ maka distribusi variabel $\mathrm{Y}$ (produktivitas kerja guru) adalah normal.

Sedangkan hasil uji linieritas diperoleh bahwa: (1) Nilai signifikansi pada linearity sebesar 0,002. Karena signifikansi kurang dari 0,05 dan deviation from linearity 0,495 yaitu lebih besar dari 0,05.maka dapat disimpulkan bahwa antara variabel supervisi akademik kepala sekolah $\left(\mathrm{X}_{1}\right)$ dan variabel produktivitas kerja guru(Y) terdapat hubungan yang linear.(2) Nilai signifikansi pada linearity sebesar 0,000. Karena signifikansi kurang dari 0,05 dan deviation from linearity 0,399 yaitu lebih besar dari 0,05.maka dapat disimpulkan bahwa antara variabel motivasi berprestasi $\left(\mathrm{X}_{2}\right)$ dan variabel produktivitas kerja guru(Y) terdapat hubungan yang linear.

Hasil pengolahan data untuk besaran pengaruh supervisi akademik kepala sekolah $\left(\mathrm{X}_{1}\right)$ secara individual (parsial) terhadap produktivitas kerja guru(Y) didapat bahwa $R$ 
Square sebesar 0,162, hal ini berarti bahwa 16,2 \% produktivitas kerja gurudipengaruhi oleh variabel supervisi akademik kepala sekolah, sedangkan sisanya 83,8 \% dipengaruhi oleh faktor lain yang tidak diteliti. Hasil pengolahan data untuk besaran pengaruh motivasi berprestasi $\left(\mathrm{X}_{2}\right)$ secara individual (parsial) terhadap produktivitas kerja guru (Y) didapat bahwa $R$ Square sebesar 0,316, hal ini berarti bahwa 31,6 \% produktivitas kerja guru dipengaruhi oleh variabel motivasi berprestasi, sedangkan sisanya 68,4\% dipengaruhi oleh faktor lain yang tidak diteliti. Sedangkan hasil pengolahan data untuk besarnya pengaruh supervisi akademik kepala sekolah $\left(\mathrm{X}_{1}\right)$ dan motivasi berprestasisecara bersama-sama (ganda) terhadap produktivitas kerja guru(Y) didapat bahwa $R$ Square sebesar 0,369, hal ini berarti bahwa $36,9 \%$ produktivitas kerja guru dipengaruhi oleh variabel supervisi akademik kepala sekolah dan motivasi berprestasi secara simultan, sedangkan sisanya 63,1\% dipengaruhi faktor lain yang tidak diteliti.

Hasil penelitian ini memberikan beberapa informasi, diantaranya: (1) Pelaksanaan supervisi akademik kepala sekolahdan motivasi berprestasi pada SMP di Kecamatan Balongan Kabupaten Indramayu memberikan pengaruh yang berarti terhadap produktivitas kerja guru SMP di Kecamatan Balongan Kabupaten Indramayu, (2) Salah satu cara untuk meningkatkan produktivitas kerja guru SMP di Kecamatan Balongan KabupatenIndramayu adalah dengan meningkatkan supervisi akademik kepala sekolahdan motivasi berprestasi. (3) Kontribusi yang diberikan oleh supervisi akademik kepala sekolah dan motivasi berprestasi secara bersama-sama terhadap produktivitas kerja guru SMP di Kecamatan Balongan Kabupaten Indramayu adalah sebesar 36,9\%, sementara sisanya dipengaruhi oleh variabel lain, yang tidak dikaji dalam penelitian ini.

\section{PENUTUP}

Beranjak dari pembahasan yang hasilnya telah disampaikan, maka dapat disimpulkan bahwa:

1) Terdapat pengaruh yang positif dan signifikan supervisi akademik kepala sekolah terhadap produktivitas kerja guru SMP Negeri di Kecamatan Balongan Kabupaten Indramayu. Adapun besaran pengaruhnya setelah melalui perhitungan regresi parsial adalah sebesar $16,2 \%$, sementara selebihnya sebanyak 83,8 \% merupakan pengaruh lain.

2) Terdapat pengaruh yang positif dan signifikan motivasi berprestasi terhadap produktivitas kerja guru SMP Negeri di Kecamatan Balongan Kabupaten Indramayu. 
Adapun besaran pengaruhnya setelah melalui perhitungan regresi parsial adalah sebesar 31,6\%, sementara selebihnya sebanyak 68,4\% merupakan pengaruh lain.

3) Terdapat pengaruh yang positif dan signifikan supervisi akademik kepala sekolah dan motivasi berprestasi secara simultan terhadap produktivitas kerja guru SMP Negeri di Kecamatan Balongan Kabupaten Indramayu. Adapun besaran pengaruhnya setelah melalui perhitungan regresi ganda adalah sebesar 36,9\%, sementara selebihnya sebanyak 63,1\% merupakan pengaruh lain.

Setelah penulis menganalisis dan menyimpulkan penelitian ini, maka dengan rendah hati penulis menyarankan, sebagai berikut:

1) Selama ini supervisi akadenik kepala sekolah telah berlangsung cukup baik. Artinya masih perlu ditingkatkan lagi, karena terbukti supervisi akademik kepala sekolah berpengaruh terhadap produktivitas kerja guru. Salah satu cara untuk meningkatkan supervisi akademik kepala sekolah adalah dengan memperbaiki perencanaan yaitu lebih melengkapi data sebelumnya agar perencanaan dibuat dengan data yang cukup, selanjutnya mengimplementasikan serta menindaklanjutinya.

2) Sesuai hasil penelitian bahwa motivasi berprestasi berpengaruh secara signifikan terhadap produktivitas kerja guru. Oleh karena itu untuk meningkatkan produktivitas kerja guru dapat dilakukan dengan cara meningkatkan motivasi berprestasi guru melalui komunikasi yang baik, pemberian tanggung jawab yang jelas dan memberikan pengakuan atau apresiasi terhadap guru yang berprestasi.

\section{UCAPAN TERIMAKASIH}

Tidak dipungkiri bahwa dalam penulisan mendapat bimbingan dan arahan, oleh karena itu penulis menyampaikan terima kasih kepada semua pihak yang telah membantu.

\section{DAFTAR PUSTAKA}

Bass, Bernard. (2001). Manajemen Sumber Daya Manusia,Cetakan kelima. Jakarta: CV. H. Masagung.

Dale Timpe. (2000). Seri Ilmu dan Seri Manajemen Bisnis: Kinerja. Jakarta: Gramedia.

Depdiknas. (2007), Perarturan-peraturan Menteri Pendidikan Nasional. Jakarta.

Fattah, Nanang. (2005).Landasan Manajemen Pendidikan, Bandung: Rosdakarya 
Glickman, Carl D. (1981), Developmental Supervision; Alternative Practice For Helping Teachers Improve Instuction. Alexandria: ASDC.

Schumacher, Sally dan Mc. Millan.J. (2001).Research in Education: New York Longman.

Wahjosumidjo. (2003). Kepemimpinan Kepala Sekolah: tinjauan teoritik dan permasalahannya. Jakarta: RahaGrafubdi Persada. 